\title{
Correction to: Public Preferences for a COVID-19 Vaccination Program in Quebec: A Discrete Choice Experiment
}

\author{
Gabin F. Morillon ${ }^{1,2,3} \cdot$ Thomas G. Poder ${ }^{1,2,3}$ (D)
}

Published online: 11 February 2022

(c) The Author(s) 2022

\section{Correction to: PharmacoEconomics https://doi.org/10.1007/s40273-021-01124-4}

In Table 2 of this article, the heading "Mixed-logit model" in the second row was mistakenly included under the column Attribute and it has now been removed from the original version.

\section{Mixed-logit model}

In Table 3 of this article, the data in the third row "Vaccine origin" was missed and it has now been updated in the original version.

\begin{tabular}{lllllll}
\hline Vaccine origin & $12.75 \%$ & $5.06 \%$ & $11.57 \%$ & $5.78 \%$ & $35.93 \%$ & $9.84 \%$ \\
\hline
\end{tabular}

The original article has been corrected.

The original article can be found online at https://doi.org/10.1007/ s40273-021-01124-4.

Thomas G. Poder

thomas.poder@umontreal.ca

1 Department of Management, Evaluation and Health Policy, School of Public Health, University of Montreal, 7101 Parc Avenue, Montreal, QC H3N 1X9, Canada

2 Centre de recherche de l'Institut universitaire en santé mentale de Montréal, CIUSSS de l'Est de l'île de Montréal, 7331 rue Hochelaga, Montreal, QC H1N 3V2, Canada

3 Centre interuniversitaire de recherche en analyse des organisations, 1130 Rue Sherbrooke O \#1400, Montreal, QC H3A 2M8, Canada
Open Access This article is licensed under a Creative Commons Attribution-NonCommercial 4.0 International License, which permits any non-commercial use, sharing, adaptation, distribution and reproduction in any medium or format, as long as you give appropriate credit to the original author(s) and the source, provide a link to the Creative Commons licence, and indicate if changes were made. The images or other third party material in this article are included in the article's Creative Commons licence, unless indicated otherwise in a credit line to the material. If material is not included in the article's Creative Commons licence and your intended use is not permitted by statutory regulation or exceeds the permitted use, you will need to obtain permission directly from the copyright holder. To view a copy of this licence, visit http://creativecommons.org/licenses/by-nc/4.0/. 